\title{
IS SELF-EXPRESSION CHIC? \\ GLOBALISATION, VALUE CHANGE AND CONVERGENCE IN LATIN AMERICA
}

\author{
A Auto-expressão é chic? Globalização, Mudança de Valores e \\ Convergência na América Latina
}

\author{
¿La autoexpresión es chic? Globalización, cambio de valores y \\ convergencia en América Latina
}

\section{Henrique Carlos DE OLIVEIRA DE CASTRO ${ }^{a}$, Daniel CAPISTRANO ${ }^{b}$ Sonia RANINCHESKI ${ }^{c}$ and Elvis BISONG TAMBE ${ }^{\mathrm{d}}$}

\footnotetext{
a. Federal University of Rio Grande do Sul. Porto Alegre, Brazil. Email: henrique@ufrg.br (1)

b. University College Dublin. Dublin, Ireland. Email: daniel.capistrano@ucd.ie (1)

c. Federal University of Rio Grande do Sul. Porto Alegre, Brazil. Email: ranincheski.s@gmail.com (1)

d. Federal University of Rio Grande do Sul. Porto Alegre, Brazil. Email: elvis.bisong@ufrgs.br (D)
}

Keywords:
self-expression;
post-materialism:
globalization;
value change;
convergence;
Latin America

Latin America

\begin{abstract}
The literature concerning human values change argues that the main factor driving increasing levels of secularization and self-expression is the improvement of material conditions. In fact, studies have succeeded in presenting evidence of a strong relationship between GDP and post-materialist attitudes at the national level. Yet, in this study, we demonstrate this relationship is not as strong in Latin America. Based on the theory of mass-elite convergence of values, we argue that the main factor driving value change in Latin America is globalization and not economic development. With globalization, attitudes and values hitherto exclusive to the elites have become socially desirable and praised (chic) resulting in their massive dissemination. Using data from the World Values Survey, we confirm that variables related to material conditions are the best predictors of secularization and self-expression among Western European countries. However, in Latin
\end{abstract}


America, the effects of economic development are weaker, and the evidence indicates that variables related to social globalization are more important to explaining patterns of value change.

Palavras-chave: auto-expressão; pósmaterialismo; globalização; mudança de valores; convergência; América Latina

\section{Resumo}

A literatura relacionada à mudança de valores humanos defende que o principal fator impulsionando os níveis de secularização e auto-expressão é a melhoria das condições materiais de vida. De fato, estudos demonstram evidência da forte relação entre Produto Interno Bruto (PIB) e atitudes pós-materialistas em nível nacional. Ainda assim, neste estudo, nós demonstramos que essa relação não é tão forte na América Latina. Baseados na teoria da convergência entre elite e massa, nós argumentamos que o principal fator impulsionando a mudança de valores na América Latina é a globalização e não o desenvolvimento econômico. Com os processos de globalização, atitudes e valores até então exclusivos das elites se tornaram socialmente desejáveis e exaltados (chic), resultando em sua disseminação em massa. Usando dados do World Values Survey (WVS), nós confirmamos que variáveis relacionadas à condições materiais são as melhores preditoras de secularização e auto-expressão entre países do Oeste Europeu. No entanto, na América Latina, os efeitos do desenvolvimento econômico são mais fracos, e a evidência indica que variáveis relacionadas à globalização social são mais importantes para explicar padrões de mudança de valores.
Palabras clave:

Autoexpresión; posmaterialismo; globalización; cambio de valores; convergencia; América Latina

\section{Resumen}

La literatura sobre el cambio de los valores humanos sostiene que el principal factor que impulsa los crecientes niveles de secularización y autoexpresión es la mejora de las condiciones materiales de vida. De hecho, estudios lograron presentar evidencia de la fuerte relación entre el Producto Interno Bruto (PIB) y las actitudes pos-materialistas a nivel nacional. Aún así, en este estudio, demostramos que esta relación no es tan fuerte en América Latina. Con base en la teoría de la convergencia de valores entre masas y élites, argumentamos que el principal factor que impulsa el cambio de valores en América Latina es la globalización y no el desarrollo económico. Con la globalización, las actitudes y valores hasta ahora exclusivos de las élites se volvieron socialmente deseables y elogiados (chic), lo que resultó en su difusión masiva. Utilizando datos de la Encuesta Mundial de Valores (WVS), confirmamos que las variables relacionadas con las condiciones materiales son el mejor predictor de la secularización y la autoexpresión entre los países de Europa Occidental. Sin embargo, en América Latina, los efectos del desarrollo económico son más débiles y la evidencia indica que las variables relacionadas con la globalización social son más importantes para explicar los patrones de cambio de valores.

\section{INTRODUCTION ${ }^{1}$}

the most widely accepted theory suggests that the socio-economic development experienced since the 1960s has created existential conditions favourable to

1. We dedicate this paper to the memory of our colleague and friend Sonia Ranincheski. 
the emergence of post-materialist and self-expression values (Inglehart \& Welzel, 2005). In this paper, we argue that, in Latin America, this increase can also be explained by an ideological convergence of mass-elite values as a result of economic and cultural globalization. This hypothesis is based on the idea that part of the general population sought to adopt attitudes and values predominant among those with higher income and educational levels, which can be seen as sophisticated, socially praised, or as we call them, "chic». This phenomenon was conceivable mainly due to the existence of two processes link with the globalization of culture: first, the sharp expansion in the audience of mass communication tools such as Radio and Television during the 1980's and 1990's, followed by the Internet, and second, the ideological power of a small and concise political and economic elite connected to other elites in Europe.

To illustrate this point, Figure 1 shows the relative frequency of the term chic among documents in Spanish from the Google Books Ngram Viewer in the period from 1800 to 2008. Even considering the serious limitation of this tool (Younes \& Reips, 2019), it is still relevant to observe that the first peak of occurrences of the word chic in Latin America was around the 1920s, which marks the beginning of cultural dissemination among the elites of the world. Still, most importantly, the period also coincided with the formation of the national elites in Latin America having higher access to European cultural products. The second surge of the word chic in Latin America occurred around the 1980s which coincided with the popularization of radio and television across the region.

Thus, using data from the World Values Survey, our results affirm the following. We demonstrate that GDP per capita and satisfaction with household financial situation are indeed the main predictors of self-expression and post-materialism in most countries, especially among high-income countries. However, an index of globalization that comprises indicators such as telephone traffic, tourism, the number of internet users is a relevant factor to explain the incidence of self-expression in Latin America. These results provide a better understanding of the interaction between culture and socio-economic development, supporting the post-materialist/self-expression theory but challenging the idea of a uniform and evolutionary value change.

This article is divided into three parts. The first part discusses the concept of post-materialism and self-expression analyzing the empirical evidence on the occurrence of these processes in different countries over the last five decades. The second part presents the main hypothesis to explain the increasing level of selfexpression in the world. At the same time, an alternative hypothesis for Latin American countries is discussed. This alternative hypothesis is based on theories related to globalization and communication. Finally, in the third part, we describe the analysis conducted to test these hypotheses and provide a discussion of the main results. 
Figure 1: Frequency of the term chic in Spanish documents from Google Ngram Viewer (1800-2000)

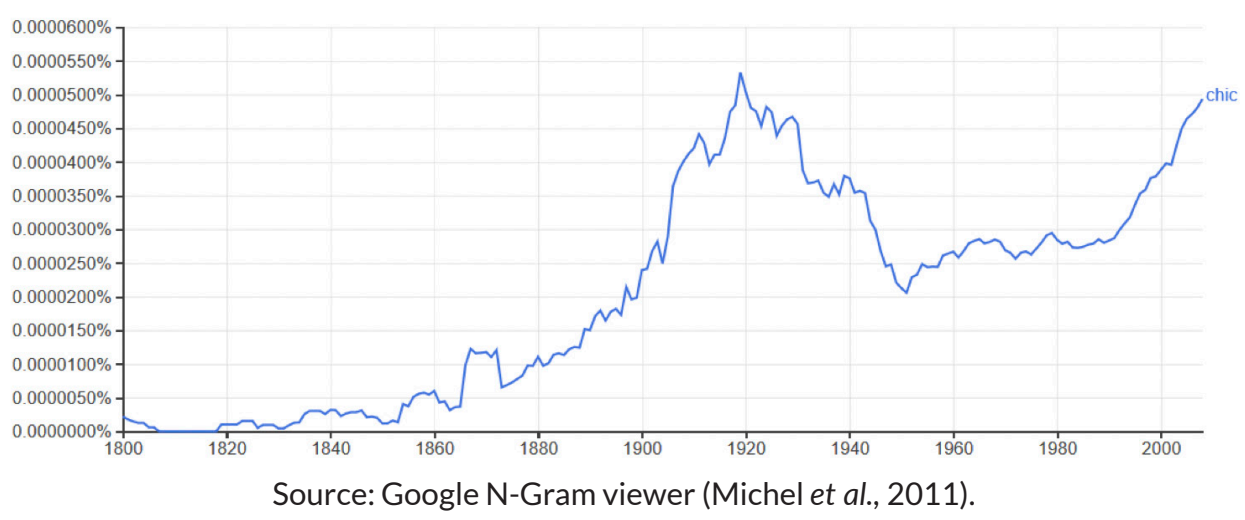

\section{CONTEXTUALISING THE PROBLEM}

Many theories of modernization have addressed the impact of the social and economic development experienced during the second half of the 20th Century, and how they are shaping a gradual transformation in culture. Proponents of Modernization Theory, such as Talcon Parsons (1964), Walter Rostow (1999) and Daniel Lerner (1968), believed that the Western model of modernity should be the basis for the development of different countries. One of the leading contemporary Modernization theories, developed by Inglehart (1993), was based on observations of mostly high-income countries. It argues that system-level changes such as economic and technological development, rising levels of education and the absence of mass violent conflicts have contributed to an increasing emphasis on needs for belonging, esteem and self-realization at the individual level. This cultural shift is characterized by a transformation of values based on economic and physical security, from materialism into values prioritizing post-materialism. Inglehart (2018) argues that the most fundamental aspect of this process is the shift from «materialistic» values (which give top priority to economic and physical security) to «post-materialist» values (which emphasize free choice and self-expression).

In a later work, Inglehart \& Welzel (2005) succeeded in testing and confirming this hypothesis of cultural shift analyzing a larger sample of countries, covering more than $80 \%$ of the world's population. In their theory of the «human development sequence», the authors argue that socio-economic development is changing human societies' cultures on two main dimensions: 1) from their emphasis on traditional values towards a secular based culture, and 2) from survival values towards 
the prioritization of self-expression. The latter dimension, survival vs. self-expression, is the main object of the present analysis. According to Inglehart and Welzel (2005, p. 49), this value change can be observed via the value priorities declared by individuals in interviews conducted by the World Values Survey. The focus on survival values is reflected in respondents who i) «[give] priority to economic and physical security over self-expression and quality of life», which is basically the materialist position in the post-materialism theory; ii) describe themselves as «not very happy»; iii) declare that homosexuality is never justifiable; iv) state that «has not and would not sign a petition, and v) affirm that "you have to be very careful about trusting people». Self-expression values, on the other hand, mean the opposite of these five statements, that is, priority to self-expression and quality of life; describe themselves as very happy; homosexuality is justifiable; the interviewee has signed a petition; shows a sense of trust in people. Combining these five characteristics, the authors created an Index that reflects the level of self-expression of each respondent which, aggregated at the national level, provides the level of self-expression values in the culture of a particular country².

The World Values Survey (WVS) is the main data source used to produce empirical evidence for the value change. Organized by a global network of social scientists, to date this cross-sectional survey has been administered for six rounds (waves) since 1981. During this period, the WVS collected data on cultural, political, and social characteristics of individuals from nationally representative samples in more than 100 societies in all inhabited continents. The WVS data indicate that self-expression levels have indeed increased among participating countries over the first six waves of the survey. The analysis of the index proposed by Inglehart among the birth cohorts presented in Figure 2 shows that younger birth cohorts have a significantly higher level of self-expression when compared to older cohorts ${ }^{3}$. The chart presents the average with the $95 \%$ confidence interval for the variable of self-expression considering all valid answers $(n=52,461)$ from all waves in 14 participating countries from Latin America and the Caribbean (LAC)4 compared to responses in Europe $^{5}(n=129,050)$ and other regions ( $\left.n=218,298\right)$.

2. The authors argue that the value change process is essentially collective and, therefore, can be analyzed at the aggregate level. For more on this debate (see, Inglehart \& Welzel, 2010).

3. The groups were created based on the variable X002 (year of birth).

4. Argentina, Bolivia, Brazil, Chile, Colombia, Dominican Rep., Ecuador, Guatemala, Mexico, Peru, Puerto Rico, Trinidad and Tobago, Uruguay, and Venezuela.

5. Western, Northern, and Southern European participating countries as defined by the World Bank Development Indicators. 
Figure 2: Mean values for the Self-Expression Index by Year of Birth and Region

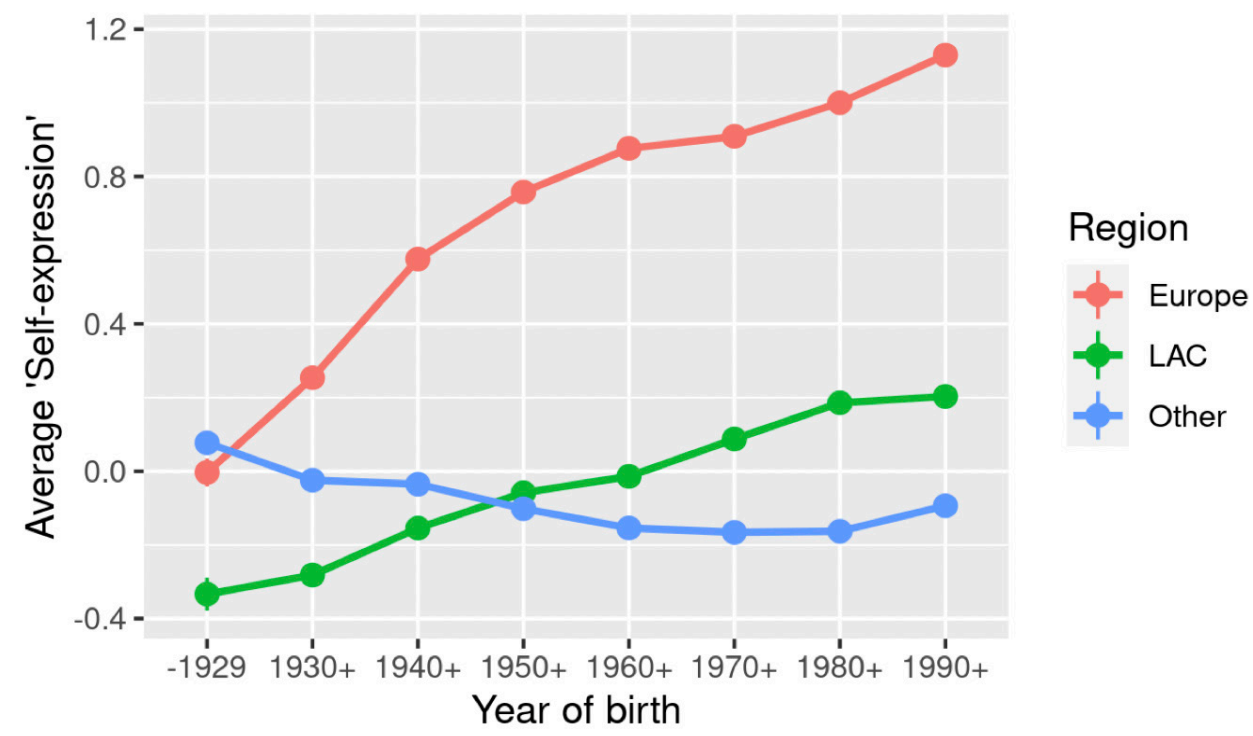

Source: European Values Study/World Values Survey Association

As shown in Figure 2, the self-expression and post-materialist values shifts seem to be present in Latin American and Caribbean countries. However, does the proposed modernization theory fully explain the presence of post-materialism and selfexpression in the region? GDP per capita and satisfaction with the household's financial situation are, in fact, the main predictors of self-expression and post-materialism in most countries, especially high-income ones. But Latin America has high inequality and high levels of poverty, which may pose a problem for the accuracy of measuring the level of post-materialism in the region. In other words, the economic growth that these countries experienced in the last decades did not represent homogeneous economic modernity for the society in general. In addition, as we discuss in this work, high levels of inequality may also be an intermediate factor between economic development and cultural shift. These initial results indicate that GDP per capita and satisfaction with the household's financial situation do not seem to be enough to explain the rise of post-materialistic values in the Latin American region. However, there is strong evidence that GDP per capita is a strong predictor of post-materialism and self-expression in Europe. Why is this not true in Latin American countries?

To address this puzzle, we propose an alternative explanation based on the theory of convergence of elite and mass values in Latin America. In short: part of the population sought to adopt attitudes and values similar to those presented by individuals with higher incomes and education levels, which can be seen as 
sophisticated or socially praised («chic»). In other words, social and cultural globalization could be a factor in explaining the incidence of relatively high self-expression levels in Latin America.

\section{THEORETICAL AND EMPIRICAL LITERATURE}

In this section, we discuss globalization as a mechanism of cultural convergence which is central in the very notion of modernization. Thus, even considering the theoretical debate of modernization that emphasizes the importance of socioeconomic development (Inglehart \& Baker, 2000), we consider globalization as a crucial element to explain the Latin American reality and the dissemination of cultural values beyond national boundaries (Bonikowski, 2010; Castro \& Ranincheski, 2013; Deutsch \& Welzel, 2016).

\section{Globalization}

The concept of globalization is controversial and it encompasses the economic, political and cultural spheres. From an economic point of view, since the early capitalism in Europe, it has presented international, multinational, transnational and world connotations, developed within the original accumulation of mercantilism, colonialism, imperialism, dependence and interdependence. This is evident in the thoughts of Adam Smith, David Ricardo, Herbert Spencer, Karl Marx, Max Weber, and many others. The current process of capitalist expansion has shortened distances, standardized productive and political relations, and has become worldwide. This process sped up the expansion of world transactions, comprising the expansion of production, finance, markets, technology, organizational regimes, institutions, enterprises and labour (Bourguignon et al., n.d.; Gray, 2009). These transformations are not confined solely to the economy but are also felt in politics, culture and domestic life. Negotiations and exchanges between individuals from different nations influence their social behaviour. Politically, globalization reaches the institutional sphere, and some political models influence national and local policies. The liberal democracy is a good example of a political model that has spread throughout different societies mainly because of globalization ${ }^{6}$. Some authors argue that major areas of human activity -culture and communications, economics

6. Although we argue that national elites were more exposed to liberal democratic values in early globalisation periods and, therefore, more inclined to accept and promote them, it is evident that, more recently, Latin American elites are not necessarily supporting or promoting democratic values. 
and politics- are at the centre of globalization processes (see, Held, McGrew, Goldblatt, \& Perraton, 2002). Notably, globalization is unleashing processes and structures that collide in new ways with the agency (and active choices) of states and societies (Akaliyski, 2019).

Globalization can be understood, in this way, as a qualitatively new phenomenon that became possible after the coincidence in time of three interdependent processes with its internal logic: the crisis and the fall of real socialism, the sharply rising development of new information and communication technologies (the so-called information era) and neoliberalism (Segrera, 2003). This relationship is, therefore, interdependent between what occurs at the local and global level regarding attitudes, values, and beliefs. In this perspective, globalization enacts the use of a distinct dimension of time, either long or short duration. In other words, if each space, country, region has its idiosyncrasies, there is a chance of the same economic, cultural or political phenomena occur in different locations at different historical moments (Arrighi, 2010).

The underlying question is whether globalization processes preserve some capitalist characteristics (such as labour exploitation and social inequalities) or if these characteristics of the world economic system explain the necessity of an economic globalization (Castells, 2005). The «human development sequence» deals with this issue indirectly. It divides the globe into different cultures in accordance with the presence of traditional or modern values and argues that society's development would change the attention of people from physical and economic concerns to more personal interests, such as self-expression and subjective wellbeing. Other authors, besides dealing with cultural values as a global and convergent possibility, investigate whether the change in social development affects the cultural change of secularism (Li \& Bond, 2010).

In order to see the effects of global processes and of the social structure in a more in-depth manner, Goldthorpe suggests relating the perspective of the global process on the part of people with their individual situation in the job market, salary, job security and perspective of progress, highlighting the material rewards and vital themes, such as housing, food and health. For the author, the labour situation focuses on issues of control, power and authority in the job and it affects the individual's degree of autonomy in the workplace and the set of control relations that act on the employee (Goldthorpe, 2012). It is necessary to highlight that both Goldthorpe and Inglehart, although departing from different theoretical perspectives, emphasize the material conditions of life for individuals for interpreting and understanding the values and attitudes prevalent in different societies. Held identifies three theoretical positions in the literature on this issue - globalism, internationalism and transformationalist (Held, 2004). The former questions whether there really is an integration of the economy, defending the regionalization of the economy as evidence of skepticism. Hyperglobalizers are at the other end of the 
vision of globalisation, conceiving the world in such an integrated way that it would be leading the world into a reality without frontiers.

Finally, the middle perspective, the transformationalists, argue that the global order is being transformed, although many of the traditional patterns continue to exist. Meyer (2007) points out that globalisation is a broad cultural phenomenon and responsible for creating many pressures and opportunities to structure and standardize national and local societies, thus producing waves of conformity with world models. The rapid compression of world society has created a richly structured environment, facilitating organization, culture and conflict in dimensions that would seem most improbable. For Meyer, individuals are increasingly structured and trained to frame their lives in the light of global standards and possibilities. In Meyer's analysis, emphasizing global education systems, it emphasizes the dissemination of individual values as well as social and economic rights -to health, education, well-being, food, work and self-development- draws attention to the paradox and global and absence of national actions in these areas. The extension of values at the global level would be less for the idea of universal values and more for international pressure for certain views.

\section{Convergence}

The process of globalization, as we have seen, enhances cultural interaction and diffusion. The issue to know how these processes of cultural dissemination in some countries tend to converge with the values disseminated in the various nations. For this debate, we point out, first, that although there are significant cultural differences between countries, negotiation is still a variable that aggregates social patterns (Welzel, 2013). There is a broad consensus on the definition of convergence as «the tendency of societies to become more similar, to develop similarities in structures, processes, and performances» (Knill, 2005, p. 766). It can be imputed to Kerr (2013) and his concern to understand the tendency for societies to become more similar, to develop similarities in structures, processes and performances. In other words, he envisions a process towards world convergence in some specific model of industrial society. Kerr's perspective is embedded in the theory of modernization, for which the convergence of political systems would lead to better technologies, better education systems and better management of the world economy, and the result would be an improvement in the quality of life. For him, however, this convergence would be blocked by rigid ideologies, nationalism and competition for resources. The theory of cultural convergence presupposes that there is a process of cultural diffusion and the possibility of convergence of values between countries (Akaliyski, 2019). 
The cultural convergence thesis is commonly used by authors to think about the countries of the European Union (Akaliyski, 2019; Goedemé \& Collado, 2016; Minkov \& Hofstede, 2012). Inspired by these studies, we consider whether this cultural convergence would not be occurring among Latin American countries, except that Latin Americans are converging towards cultural values exogenous to their continent and closer to values found outside this region. From Akaliyski's study, in Latin American countries there is no institutional process - such as EU constraintsto force to incorporate post-materialistic values. Thus, it is likely that the explanation for the convergence of values found in LAC is in other dimensions, and one of them may be the influence of these elites from the chic culture. That is, for LAC countries to present values such as those of the developed world could represent an image production similar to those in Europe.

In the discussion of cultural diffusion for the European case, the process would occur in three mechanisms, namely: (1) vertical diffusion (trickle down) of values, in the sense of the process of becoming similar to each other (isomorphism) operating through coercion, mimicry and normative isomorphism (DiMaggio \& Powell, 1983); (2) horizontal diffusion of values, directed or not (hybridization theory); and (3) convergence of living standards (Akaliyski, 2019). Consequently, we can agree with Seeliger's (1996) statement that there is no consensus on the degree of convergence of transnational policies that are still not well understood (Seeliger, 1996). Scholars of economic development in the 1990s worked with the hypothesis that, at least since World War II and perhaps for a considerable period before, the group of industrialized countries was becoming increasingly homogeneous in terms of productivity levels, technology and per capita income. For these authors, the convergence of ideas between entrepreneurs from different countries and a kind of «Convergence Club» of entrepreneurs (Baumol, Nelson, \& Wolff, 1994) is occurring.

The central idea is that many people across developing countries have a lifestyle that is similar or aspires that of the United States and other developed countries because of the exchange of technological information. In other words, entrepreneurs from developing countries imitate their colleagues from advanced countries (Conesa, 1994, p. 23). Education and income levels played an important role in this process, since they facilitate the apprehension of the dynamics established in the richer countries. Conesa's perspective of convergence is relevant to think about how the apprehension of post-materialist values occurs. Another relevant issue is the role of inequality in this process. In highly unequal societies, such as those in Latin America, the promise of social mobility is strongly attached to the cultural values of those in the elite. Therefore, the chic culture is valued, aspired and promoted across the population as means for social recognition.

Our conceptualization of globalization and cultural convergence differs from those traditional studies on foreign influence in the formation of 
nineteenth-century Latin American social thought. In these studies, authors affirm the absorption of European ideas as a case of mechanical import of ideas and in disagreement with Latin American political and economic reality, in a kind of out of place ideas (Schwarz, 2014). Other authors, in opposition, see such influence as an inherent part of the dynamics of the circulation of ideas within the same productive system, capitalism (Carvalho Franco 1976: 62). More recently there is thinking about the coloniality of power, of knowledge (Quijano, 2014). In this article, we point out the importance of discussing the values present in Latin American societies by considering globalization and cultural convergence as part of a process that may be building a similar system of values independent of the material realities of societies.

\section{METHODS AND DATA}

To examine the factors that drive post-materialism and self-expression in Latin American countries at the individual level, this study uses data from the World Values Survey combined with national-level socio-economic and globalization indicators. The World Values Survey is a cross-sectional comparative survey administered since 1981 by a consortium of social scientists based in all inhabited continents. A nationally-representative sample of adults is interviewed face-toface using a common core questionnaire. For this work, we have used the pooled dataset combining all seven waves administered from 1981 to 2018 in Latin American and European countries. This resulted in a sample of 164 country/waves and 181,511 respondents with valid observations for the main outcome variable.

The analysis is conducted in two stages. First, we assess factors related to post-materialism and self-expression at the national level using country-wave as the unit of analysis. After that, we conduct a multilevel analysis incorporating the national-level indicators to the individual-level data produced by the World Values Survey (Inglehart et al., 2014). Apart from the main outcome variable (self-expression) discussed previously, we have also selected the Post-Materialism Index (12-item) as an outcome variable for analysis. In addition, at the individual level, we have selected variables related to socio-economic characteristics such as age, gender, educational level and satisfaction with financial situation of household. These are all variables that should have a positive effect on the individual level of self-expression as well as of post-materialism.

Furthermore, we have combined the WVS dataset with national-level indicators. The Gross Domestic Product (GDP) per capita provides an indication of the sum of gross value generated by the national economy divided by the midyear population. Despite the conceptual issues involving the use of GDP as a measurement of material conditions of a society (Costanza et al., 2014), this indicator is widely used 
as one of the main explanatory variables for self-expression and post-materialism. The source of this data is the World Bank. In addition, we have also analysed the association between self-expression and the Human Development Index (HDI) as measured by the United Nations Development Programme (UNDP). For the WVS data regarding 2018, we have used the most recent published 2017 HDI.

Finally, to test the hypothesis that the level of globalization is a relevant variable to explain rising levels of self-expression and post-materialism, we have used data from the KOF Social Globalization Index (Dreher, 2006; Gygli, Haelg, Potrafke, \& Sturm, 2019). This Index is part of a broader project that aims to assess the level of economic, social and political integration among countries across the globe. The Social Globalization index results from the aggregation of 10 indicators (see Appendix, Table 1A) based on data related to personal contacts, information flows, and cultural proximity. As with the HDI, the 2017 values for the Social Globalization Index were associated to the WVS observations from 2018, as this Index has not yet been updated for 2018 .

\section{MAIN HYPOTHESIS}

The main factor proposed by Inglehart (1990) to explain the movement towards post-materialism and self-expression is the existence of economic and physical security during the socialization period of younger cohorts. The proxy variable used to measure levels of economic and physical security is the Gross Domestic Product (GDP) per capita, assuming that higher levels of national wealth will generate better existential conditions for younger cohorts. Responding to criticism for using GNI or GDP to assess the factors driving value change, Inglehart (2018, p. 15) argues that «Per capita income is one of the best readily-available indicators of the conditions leading to this value shift, but the theoretically crucial factor is one's sense of existential security». In the absence of better measurements of economic and physical security, we have used the same variable suggested by the authors and verified that, in fact, there is a positive high correlation between GDP per capita $^{7}$ and the self-expression index as shown in Figure 3.

7. World Bank - GDP per capita (constant 2010 US\$). Indicator ID: «NY.GDP.PCAP.KD». 


\section{Figure 3: Self-Expression and GDP per capita 1981-2018 in WVS participant countries}

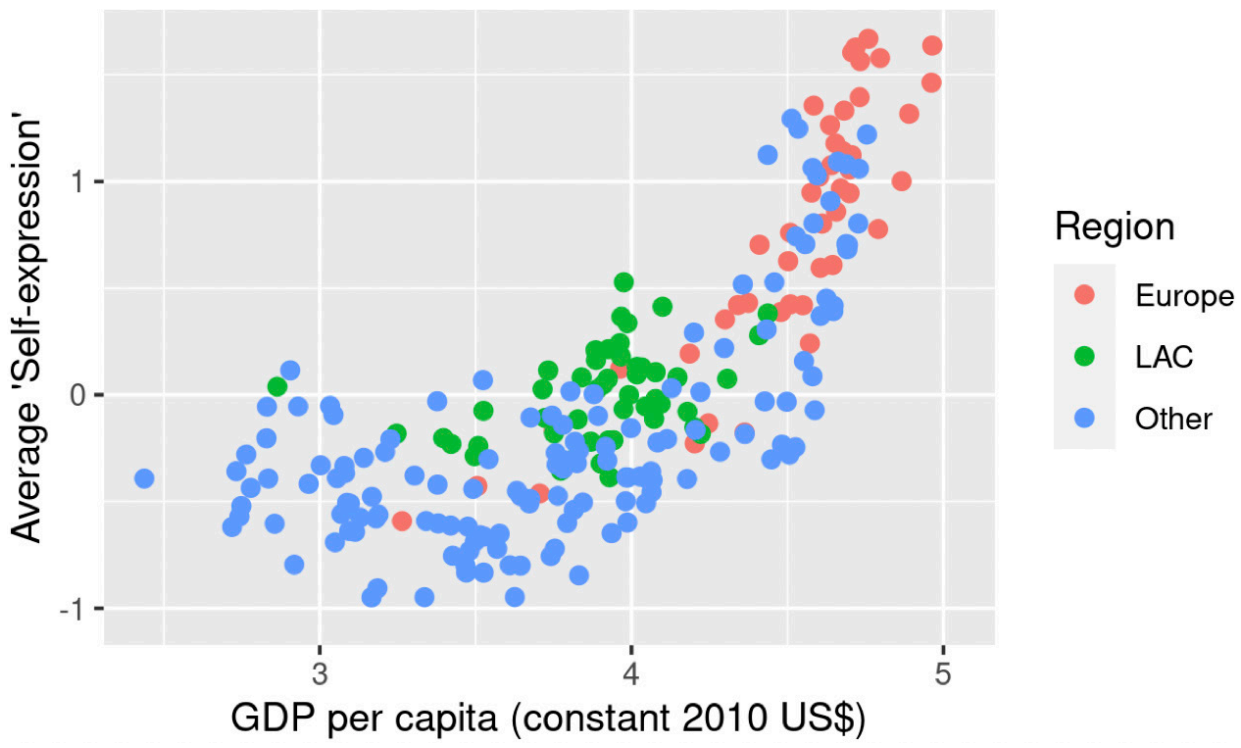

Notes: Integrated File. EVS_WVS_Integrated_WV1_7_sav_v20190815.sav and World Bank. Notes: $\mathrm{N}=224, \mathrm{r}=.86$. Results weighted by $\mathrm{S} 018$.

Source: European Values Study/World Values Survey Association.

\section{Alternative hypothesis}

In Latin America, the GDP per capita has indeed increased during the period studied. However, as Figure 3 indicates, the relationship between income per capita and self-expression is not as straightforward as the global correlation would suggest. The lack of substantial variation in the income per capita in LAC countries compared to all WVS countries, does not allow for conclusions regarding the relationship between these two variables in the region. However, in a comparative perspective, it is worth noting that Latin American Countries show the highest levels of self-expression among low and middle-income countries. Uruguay, for instance, has the same level of self-expression of Germany. Mexico is at similar level of Japan and Spain. What could explain this portion of the self-expression values that are not explained by income?

We suggest that in addition to income or increasing levels of economic and physical security, Latin American societies are particularly susceptible to adopting 
self-expression values of their elites. These elites, in turn, would adopt values of self-expression because they are affected by cultural dissemination as a result of globalization itself, together with increasing access to mass media resulting in a convergence of values between elites and mass. This access to mass media, globalized, is a phenomenon understood as media convergence (Jenkins, 2016) and would facilitate this cultural dissemination.

\section{RESULTS AND INTERPRETATION}

The linear bivariate relationships shown in Figure 4, at the national level, indicates a positive association between the level of social globalization and the national average of self-expression values. The correlation coefficient suggests a stronger association of self-expression with the Social Globalization Index $(r=0.48)$ than with the Human Development Index ( $r=0.30)$ and GDP per capita $(r=0.40)$.

Figure 4: Average self-expression and GDP per capita, Human Development Index and Social globalisation Index (1981-2014) in Latin American countries

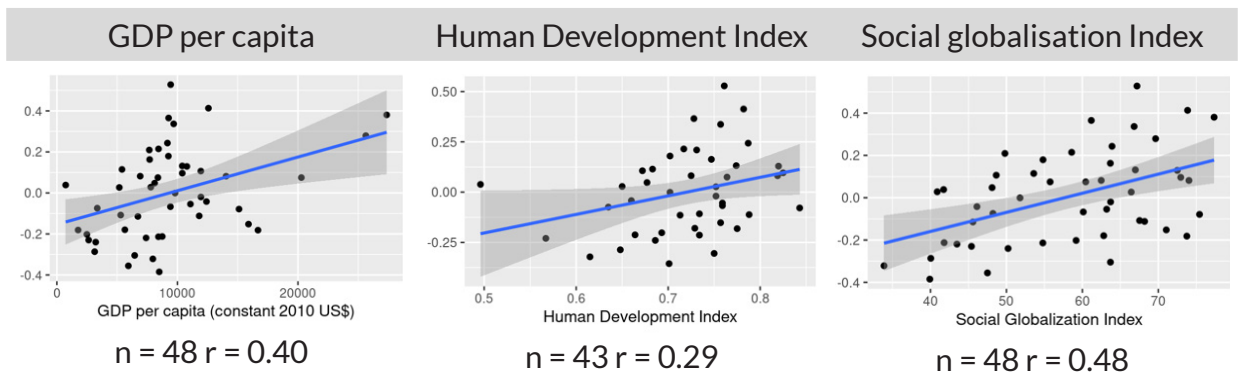

Source: WORLD VALUES SURVEY 1981-2014 LONGITUDINAL AGGREGATE v.20150418. World Values Survey Association.

Aggregate File and World Bank.

The association between these socio-economic variables and the proportion of post-materialists in the country is considerably different. In general, the correlation coefficients are lower, the strongest association is observed with the HDI $(r$ $=0.23)$, followed by GDP $(r=0.14)$ and the Social Globalization Index $(r=0.13)$. However, these correlations do not provide sufficient evidence as to the relative importance of globalization over material conditions. To estimate the effect of both variables (social globalization and GDP per capita) over self-expression and post-materialism, we have fit multilevel linear regression models (Bates, Mächler, Bolker, \& Walker, 2015) using the country/wave GDP per capita and Social 
Globalization Index at level 2. This model includes the following control variables at the individual level: "Age», "Gender», and «Satisfaction with financial situation of household». Table 1 below presents the standardized coefficients for each variable followed by their confidence interval and $p$-value.

Table 1. Multilevel regression models for self-expression in Latin America and the Caribbean and Europe

\begin{tabular}{|c|c|c|c|c|c|c|}
\hline \multirow[b]{2}{*}{ Predictors } & \multicolumn{3}{|c|}{ Latin America and Caribbean } & \multicolumn{3}{|c|}{ Europe } \\
\hline & $\begin{array}{l}\text { Std. } \\
\text { Coeff }\end{array}$ & $\mathrm{Cl}$ & $\mathrm{p}$ & $\begin{array}{l}\text { Std. } \\
\text { Coeff }\end{array}$ & $\mathrm{Cl}$ & $\mathrm{p}$ \\
\hline (Intercept) & 0.04 & $-0.01-0.09$ & 0.14 & 0.53 & $0.46-0.59$ & $<0.001$ \\
\hline Female (ref.: Male) & -0.05 & $-0.07--0.04$ & $<0.001$ & 0 & $-0.01-0.01$ & 0.895 \\
\hline Age & -0.12 & $-0.13--0.11$ & $<0.001$ & -0.25 & $-0.25--0.24$ & $<0.001$ \\
\hline $\begin{array}{l}\text { Satisfaction with household } \\
\text { Ofinancial situation }\end{array}$ & 0.12 & $0.11-0.13$ & $<0.001$ & 0.18 & $0.17-0.18$ & $<0.001$ \\
\hline GDP per capita & 0.05 & $-0.01-0.10$ & 0.096 & 0.27 & $0.15-0.38$ & $<0.001$ \\
\hline Social Globalisation Index & 0.08 & $0.02-0.14$ & 0.01 & 0.23 & $0.14-0.33$ & $<0.001$ \\
\hline Countries & \multicolumn{3}{|l|}{46} & \multicolumn{3}{|l|}{63} \\
\hline Observations & \multicolumn{3}{|l|}{48,041} & \multicolumn{3}{|c|}{60,060} \\
\hline Marginal R2 / Conditional R2 & \multicolumn{3}{|c|}{$0.064 / 0.111$} & \multicolumn{3}{|c|}{$0.284 / 0.347$} \\
\hline ICC & \multicolumn{3}{|l|}{0.05} & \multicolumn{3}{|l|}{0.09} \\
\hline AIC & \multicolumn{3}{|c|}{111197.066} & \multicolumn{3}{|c|}{140266.640} \\
\hline
\end{tabular}

Source: WORLD VALUES SURVEY 1981-2014 LONGITUDINAL AGGREGATE v.20150418.

World Values Survey Association). Aggregate File, World Bank, and Gygli et al., 2019.

Significance: ${ }^{* * *} p<0.001 ;{ }^{* *} p<0.01 ;{ }^{*} p<0.05$.

The comparison of the overall fit of these models suggests that the selected explanatory variables more consistently predict individual levels of self-expression in Europe than in Latin America. As expected, and suggested by previous research (Inglehart \& Welzel, 2005), younger respondents present higher levels of selfexpression in Latin America and Europe. Being more satisfied with one's financial situation is also associated with higher self-expression in both regions, which also confirms Inglehart's modernization theory. Interestingly, gender differences are 
only statistically significant in Latin American countries, where women tend to present lower levels of self-expression compared to men. More importantly, confirming our hypothesis, even controlling for these individual characteristics, the level of social globalization has a significant effect on the variation of self-expression in Latin American countries. The same is true for European countries, however, also supporting the alternative hypothesis, the models do not provide evidence that the effect of the GDP per capita is significant in Latin American countries.

Similar to what was found in the bivariate analysis, these individual and national explanatory variables are not so relevant to explaining the proportion of post-materialists in the country. In Latin America, neither the GDP nor the Social Globalisation Index are statistically significant, whereas both indicators show statistical significance for European countries. Given the low number of observations at level 2, we have also analyzed the aggregated mean level of self-expression at the national level through a regular linear multiple regression with only two predictors: GDP per capita and Social Globalisation Index. The results using this approach corroborate the evidence from the individual-level variation. The model has higher explanatory power for European countries where both the GDP and Social Globalization Index are statistically significant and account for $73 \%$ of the variance in self-expression at the national level. On the other hand, in Latin America, GDP per capita does not have statistical significance in this model, and the two variables explain only $22 \%$ of the variation at the national level.

\section{CONCLUSION}

In the past four decades, the Latin American region has experienced the implementation of authoritarian policies by liberal governments that go in the opposite direction of an environment that promotes self-expression and post-materialism. Even so, post-materialism and self-expression are becoming increasingly prevalent in Latin America and the Caribbean. It is from this contrast between the presence of values of self-expression and a society with high levels of social inequality and economic insecurity that we propose an alternative explanation for this cultural shift in the region. We suggest that the mass dissemination of symbols, images, and world views of the elite (seem as "chic») is the main driver of cultural change in these societies. We argued that high level of social and income inequality is an important factor to understand this unique phenomenon in the region. Cultural values promoted by the elites become prevalent in society as they are strongly attached to the idea of social mobility, in other words, these values become the reference for what should be pursued, socially praised. In this sense, as we demonstrated in this paper, the main factors driving this cultural shift in Latin America are 
indeed substantially different to the explanation provided by the main studies on the topic (Inglehart, 2018; Inglehart \& Welzel, 2005).

Using data from the World Values Survey, we have shown that the presence of these values cannot be entirely explained by the modernization theory developed by Inglehart and Welzel (2015). The GDP per capita and household financial satisfaction are, in fact, highly correlated with self-expression and post-materialism in most countries, especially among high-income countries. However, looking at the specific group of Latin American countries the picture is considerably different. The usual explanatory variables (age, GDP per capita and satisfaction with the financial situation) are not as powerful predictors of self-expression as they are in European countries. We then tested other crucial element to explain the increase in post-materialism and self-expression among Latin Americans. We suggested incorporating globalization and convergence theory as an alternative to explain the rise in self-expression. The results suggest that globalization has a greater impact on the individual level of self-expression among Latin Americans, whereas GDP per capita is not a statistically significant variable, which is in line with our theoretical expectation. Globalization is, thus, also a process of cultural expansion and influences areas of human activity culture and communications, economics and politics ( see Held et al., 2002; Arrighi, 2010). In addition, our results corroborate Meyer's (2007) assertion that globalisation is a phenomenon that creates many pressures and opportunities to structure and standardize national and local societies, thus producing waves of conformity with world models. Thus, in contrast with the European cultural convergence, where there are clear constraints and norms that impose policies towards self-expression values, in Latin America, the cultural, social and economic processes associated with globalization play a more important role.

Apart from these results in relation to self-expression levels in Latin America, we could not find clear evidence for the impact of social globalization on postmaterialism. In general, this outcome variable is not well explained with the predictor variables that we have selected for this study. Despite the high correlation between self-expression and post-materialism, the latter seems to encapsulate different dimensions of culture that cannot be investigated only through the lens of the modernization or convergence theories. Finally, taken as a whole, our results provide concise and clear evidence that the cultural change (Inglehart, 2018; Inglehart \& Welzel, 2005) is not a uniform and homogeneous process. Although we can indeed observe indications of a general shift across cultures, there is no evidence that these values and attitudes are changing in the same direction and, more importantly, the mechanisms that drive these changes may be different in different societies. In addition, our work emphasises the need for scholars and analysts to focus on specific national cases in Latin America to better understand the role of globalization on cultural change. 
HENRIQUE CARLOS DE OLIVEIRA ET AL.

IS SELF-EXPRESSION CHIC? GLOBALISATION, VALUE CHANGE AND CONVERGENCE IN LATIN AMERICA

\section{BIBLIOGRAPHY}

Akaliyski, P. (2019). United in diversity? The convergence of cultural values among EU member states and candidates. European Journal of Political Research, 58(2), 388-411. https:// doi.org/10.1111/1475-6765.12285.

Arrighi, G. (2010). The long twentieth century: Money, power, and the origins of our times («New and updated ed.»-- Cover). London; New York: Verso.

Bates, D., Mächler, M., Bolker, B., \& Walker, S. (2015). Fitting Linear Mixed-Effects Models Using Ime4. Journal of Statistical Software, 67(1). https://doi.org/10.18637/jss.v067.i01

Baumol, W. J., Nelson, R. R., \& Wolff, E. N. (1994). Convergence of productivity: Cross-national studies and historical evidence. Retrieved from http://site.ebrary.com/id/10087211

Bonikowski, B. (2010). Cross-national interaction and cultural similarity: A relational analysis. International Journal of Comparative Sociology, 51(5), 315-348. https://doi. org/10.1177/0020715210376854.

Bourguignon, F., Coyle, D., Fernàndez, R., Giavazzi, F., Marin, D., O'Rourke, K., ... Winters, L. A. (n.d.). Making Sense of Globalization: A Guide to the Economic Issues. Retrieved from https://ideas.repec.org/b/lmu/muenbk/20240.html.

Castells, M. (2005). La sociedad red (3. ed). Madrid: Alianza Ed.

Castro, H. C. de O. de, \& Ranincheski, S. (2013). A internacionalização da democracia: A universalização dos valores liberais. Revista de Estudos e Pesquisas sobre as Américas, 7(1), 116-133.

Conesa, E. R. (1994). Los secretos del desarrollo: Claves para entender y superar el estancamiento de la Argentina de hoy. Buenos Aires: Planeta. 22

Costanza, R., Kubiszewski, I., Giovannini, E., Lovins, H., McGlade, J., Pickett, K. E., ... Wilkinson, R. (2014). Development: Time to leave GDP behind. Nature News, 505(7483), 283. https://doi.org/10.1038/505283a.

Deutsch, F., \& Welzel, C. (2016). The Diffusion of Values among Democracies and Autocracies. Global Policy, 7(4), 563-570. https://doi.org/10.1111/1758-5899.12388.

DiMaggio, P. J., \& Powell, W. W. (1983). The Iron Cage Revisited: Institutional Isomorphism and Collective Rationality in Organizational Fields. American Sociological Review, 48(2), 147-160. https://doi.org/10.2307/2095101.

Dreher,A.(2006).Doesglobalizationaffectgrowth?Evidencefromanewindexofglobalization. Applied Economics, 38(10), 1091-1110. https://doi.org/10.1080/00036840500392078.

Goedemé, T., \& Collado, D. (2016). The EU Convergence Machine at Work. To the Benefit of the EU's Poorest Citizens? JCMS: Journal of Common Market Studies, 54(5), 1142-1158. https://doi.org/10.1111/jcms.12382.

Goldthorpe, J. H. (2012). De vuelta a la clase y el estatus: Por qué debe reivindicarse una perspectiva sociológica de la desigualdad social. Revista Española de Investigaciones Sociológicas, 137. https://doi.org/10.5477/cis/reis.137.43.

Gray, J. (2009). False dawn: The delusions of global capitalism. London: Granta.

Gygli, S., Haelg, F., Potrafke, N., \& Sturm, J.-E. (2019). The KOF Globalisation Index - revisited. The Review of International Organizations, 14(3), 543-574. https://doi.org/10.1007/ s11558-019-09344-2.

Held, D. (2004). A globalizing world? Culture, economics, politics. London; New York: Routledge in association with the Open University.

Held, D., McGrew, A. G., Goldblatt, D., \& Perraton, J. (Eds.). (2002). Global transformations: Politics, economics and culture. Stanford, Calif: Stanford Univ. Press. 


\section{APPENDIX}

Table 1A: Components of the Social Globalisation Index

\begin{tabular}{|c|c|c|}
\hline \multicolumn{3}{|c|}{ i) Data on Personal Contact } \\
\hline Telephone Traffic & $\begin{array}{l}\text { International } \\
\text { Telecommunication } \\
\text { Union (2015) }\end{array}$ & $\begin{array}{l}\text { International voice traffic is the sum of } \\
\text { international incoming and outgoing fixed } \\
\text { telephone traffic (in minutes per person). }\end{array}$ \\
\hline $\begin{array}{l}\text { Transfers (percent } \\
\text { of GDP) }\end{array}$ & World Bank (2016) & $\begin{array}{l}\text { Sum of gross inflows and gross outflows of } \\
\text { goods, services, income, or financial items } \\
\text { without a quid pro quo. Data are in percent } \\
\text { of GDP. }\end{array}$ \\
\hline $\begin{array}{l}\text { International } \\
\text { Tourism }\end{array}$ & World Bank (2016) & $\begin{array}{l}\text { Sum of arrivals and departures of } \\
\text { international tourists as a share of } \\
\text { population. }\end{array}$ \\
\hline $\begin{array}{l}\text { Foreign Population } \\
\text { (percent of total } \\
\text { population) }\end{array}$ & World Bank (2016) & $\begin{array}{l}\text { Foreign population is the number of } \\
\text { foreign or foreign-born residents in a } \\
\text { country. Data are in percent of total } \\
\text { population. }\end{array}$ \\
\hline $\begin{array}{l}\text { International } \\
\text { letters (per capita) }\end{array}$ & $\begin{array}{l}\text { Universal Postal } \\
\text { Union, Postal } \\
\text { Statistics database }\end{array}$ & $\begin{array}{l}\text { Number of international letters sent and } \\
\text { received per capita. }\end{array}$ \\
\hline \multicolumn{3}{|c|}{ ii) Data on Information Flows } \\
\hline $\begin{array}{l}\text { Internet Users } \\
\text { (per } 100 \text { people) }\end{array}$ & World Bank (2016) & $\begin{array}{l}\text { Internet users are people with access to } \\
\text { the worldwide internet network. }\end{array}$ \\
\hline $\begin{array}{l}\text { Television (per } 100 \\
\text { people) }\end{array}$ & $\begin{array}{l}\text { World Bank (2007), } \\
\text { International } \\
\text { Telecommunication } \\
\text { Union (2015) }\end{array}$ & Share of households with a television set. \\
\hline $\begin{array}{l}\text { Trade in } \\
\text { Newspapers } \\
\text { (percent of GDP) }\end{array}$ & $\begin{array}{l}\text { United Nations } \\
\text { Commodity Trade } \\
\text { Statistics Database } \\
\text { (2016) }\end{array}$ & $\begin{array}{l}\text { The sum of exports and imports in } \\
\text { newspapers and periodicals in percent of } \\
\text { GDP. Data are provided by the Statistical } \\
\text { Division of the United Nations and } \\
\text { correspond to those published in the U.N. } \\
\text { World Trade Annual. }\end{array}$ \\
\hline
\end{tabular}


iii) Data on Cultural Proximity

Number of McDonald's Restaurants (per 100 '000 people)

Number of Ikea (per 100'000 people) various sources

Ikea
Number of McDonald's Restaurants (per capita).

Source: Gygli et al. (2019).

Table 2A: Multilevel regression models for post-materialist in Latin America and Europe

\begin{tabular}{|c|c|c|c|c|c|c|}
\hline \multirow[b]{2}{*}{ Predictors } & \multicolumn{3}{|c|}{ Latin America } & \multicolumn{3}{|c|}{ Europe } \\
\hline & Estimates & $\mathrm{Cl}$ & $p$ & Estimates & $\mathrm{Cl}$ & $p$ \\
\hline (Intercept) & 2.25 & $2.18-2.32$ & $<0.001$ & 2.43 & $2.35-2.51$ & $<0.001$ \\
\hline Female (ref: Male) & -0.04 & $-0.05--0.02$ & $<0.001$ & 0.02 & $-0.00-0.03$ & 0.076 \\
\hline Age & -0.11 & $-0.12--0.10$ & $<0.001$ & -0.22 & $-0.23--0.21$ & $<0.001$ \\
\hline $\begin{array}{l}\text { Satisfaction with } \\
\text { financial situation }\end{array}$ & 0.03 & $0.02-0.04$ & $<0.001$ & 0.02 & $0.01-0.03$ & 0.001 \\
\hline GDP per capita & 0.05 & $-0.02-0.12$ & 0.169 & 0.16 & $0.02-0.29$ & 0.022 \\
\hline $\begin{array}{l}\text { Social Globalisation } \\
\text { Index }\end{array}$ & -0.04 & $-0.12-0.04$ & 0.344 & 0.23 & $0.11-0.35$ & $<0.001$ \\
\hline Countries & 46 & & & 54 & & \\
\hline Observations & 54,792 & & & 64,406 & & \\
\hline $\begin{array}{l}\text { Marginal R2 / } \\
\text { Conditional R2 }\end{array}$ & $0.011 / 0.0$ & & & $0.102 / 0.1$ & & \\
\hline
\end{tabular}

Source: WORLD VALUES SURVEY 1981-2014 LONGITUDINAL AGGREGATE v.20150418. Aggregate File, World Bank, and Gygli et al. (2019).

Significance: ${ }^{* * *} p<0.001 ;{ }^{* *} p<0.01 ;{ }^{*} p<0.05$ 